University of Rhode Island

DigitalCommons@URI

The Rhode Island Current Conditions Index

Economics

$11-1-2020$

\title{
Rhode Island Current Conditions Index - November 2020
}

Leonard Lardaro

University of Rhode Island, lardaro@uri.edu

Follow this and additional works at: https://digitalcommons.uri.edu/ricci

Part of the Econometrics Commons

Terms of Use

All rights reserved under copyright.

\section{Recommended Citation}

Lardaro, Leonard, "Rhode Island Current Conditions Index -- November 2020" (2020). The Rhode Island Current Conditions Index. Paper 214.

https://digitalcommons.uri.edu/ricci/214

This Newsletter is brought to you for free and open access by the Economics at DigitalCommons@URI. It has been accepted for inclusion in The Rhode Island Current Conditions Index by an authorized administrator of DigitalCommons@URI.For more information, please contact digitalcommons-group@uri.edu. 


\title{
CURRENT CONDITIONS
}

\section{LEONARD LARDARO, URI}

\author{
Available Online: http: / www.Ilardaro.com/current.htm \\ Twitter: @ladardo
}

VOL XXVIT

NUMBER 12

NOV 2020

Things have been abysmal since the pandemic hit, but not as bad as the initial few months. Amid fiscal and monetary policy measures that helped boost our state's economy, we began to move upward. On a yearly basis, though, we remain very far below where we were, or for that matter, where I ever thought we would be. This has been readily apparent in Current Conditions Index values, which quickly fell from 75 in February, as nine indicators improved, to 33 in March, then about as bad as it gets, with CCI values of 8 for both April and May, with only a single indicator improving each month. We then "improved" to values of 25 for the next several months and have largely plateaued there ever since. In October, the CCI fell back to 17, with the direction of change more disappointing than the actual CCI value itself. Was our momentum fading, as was true for the national economy, the result of ever-smaller stimulus impact since further stimulus had not been forthcoming? Looking at the recent behavior of individual indicators, this is continuing even now with a new fiscal package having been passed, the result of lagged impacts.

For November, there was a slight change in what was occurring. The November CCI rose from its prior value of 17 to 25, with three indicators improving. That's the good news (I guess!). Throughout this entire time, two indicators, Retail Sales and the Manufacturing Wage have continued to improve. Of these, Retail Sales has been the strongest and most consistently improving indicator, benefitting in part from changes in behavior dictated by the pandemic and the increased inequality it has produced. For manufacturing, however, the proxy for manufacturing output, Total Manufacturing Hours, a critical

\begin{tabular}{|c|c|}
\hline \multicolumn{2}{|c|}{ CCI Indicators - \% Change } \\
\hline Government Employment & -2.9 \\
\hline US Consumer Sentiment & -20.5 \\
\hline Single-Unit Permits & $34.3 Y$ \\
\hline Retail Sales & $10.0 Y$ \\
\hline Employment Services Jobs & -14.3 \\
\hline Priv. Serv-Prod Employment & -9.0 \\
\hline Total Manufacturing Hours & -6.2 \\
\hline Manufacturing Wage & $9.5 Y$ \\
\hline Labor Force & -2.9 \\
\hline Beneffit Exhaustions & $\mathbf{5 7 8 . 7}$ \\
\hline New Claims & 447.5 \\
\hline Unemployment Rate (change) & 3.8 \\
\hline
\end{tabular}

leading economic indicator, has displayed persistent weakness, failing to improve even once. While the Manufacturing Wage has continued to rise, its changes reflect differences in the composition of monthly job changes in manufacturing. If one believes the recent data, durable goods manufacturing employment, the most cyclical portion of manufacturing employment, has changed very little in recent months while the durable goods workweek has fallen a great deal. This is not necessarily what one would expect to see, although for most of us, this is our first pandemic (thank God!). At least Single-Unit Permits, reflective of new home construction, improved in November for the first time since August.

This brings me to another factor to consider: The data for October through December are those most distant from known values, and thus the most likely to be revised. My guess is that manufacturing employment may well be revised somewhat lower, although it is anyone's guess the role seasonal adjustment is playing in this. Benefit Exhaustions and New Claims, both of which are not survey based, remain five to six times their prior year values.

All of these things led me to calculate the CCI on a monthly basis, ultimately to ascertain if we were making progress towards an ultimate recovery, a sustained period of increasing overall activity that begins with monthly improvements. Looking at the CCI based on monthly changes (table below), the November monthly CCI fell back to 42, a contraction value following two months of improvement. I will therefore have to put possibility that Rhode Island is in the earliest stages of a recovery on hold for now. Perhaps the new fiscal stimulus will soon change this. Let's hope!

\begin{tabular}{|c|c|}
\hline CCI Indicators - Monthly \% & Chang \\
\hline Government Employment & 0.0 \\
\hline US Consumer Sentiment & -4.7 \\
\hline Single-Unit Permits & $24.4 Y$ \\
\hline Retail Sales & $1.9 \mathrm{Y}$ \\
\hline Employment Services Jobs & $0.6 \mathrm{Y}$ \\
\hline Priv. Serv-Prod Employment & -0.2 \\
\hline Total Manufacturing Hours & -0.2 \\
\hline Manufacturing Wage & -1.5 \\
\hline Labor Force & -0.3 \\
\hline Benefit Exhaustions & $-46.6 Y$ \\
\hline New Claims & $-0.3 Y$ \\
\hline Unemployment Rate (change) & 0.2 \\
\hline $\mathbf{Y}=$ Improved Value & \\
\hline
\end{tabular}

$\begin{array}{rcc}\text { LABOR FORCE: } & \text { NOV 2020 } & \text { Peak (1/2007) } \\ \text { Participation Rate } & 62.5 \% & 68.6 \% \\ \text { Employment Rate } & 58.0 \% & 65.4 \%\end{array}$

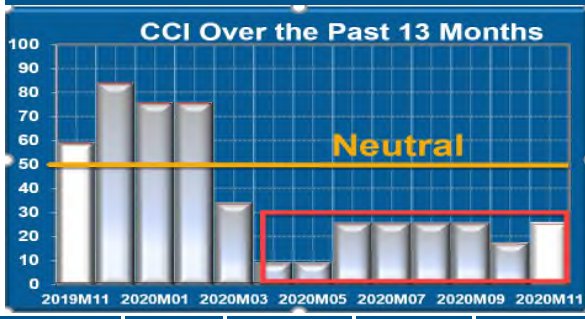

DLT NOV 2020

$(\mathbf{S A}, \mathbf{Y} / \mathbf{Y})$

Gain

0

Loss

37,700

Net Chg $(37,700)$

\begin{tabular}{|c|c|c|c|c|c|c|c|c|c|c|c|c|}
\hline & Jan & Feb & Mar & Apr & May & Jun & Jul & Aug & Sep & Oct & Nov & Dec \\
\hline 2019 & $58 \downarrow$ & $50 \uparrow$ & 58 & $50 \downarrow$ & $50 \downarrow$ & $58 \downarrow$ & $75 \downarrow$ & 67 & $50 \downarrow$ & $75 \downarrow$ & $58 \downarrow$ & $83 \downarrow$ \\
\hline 2020 & 75 & 75 & & & & $\uparrow$ & & & & & & \\
\hline
\end{tabular}

Gopyright ( 2019,2020 Leonard Lardaro, Ph.D. All rights reserved. 